\title{
Igneous intrusions in the cored Upper Jurassic succession of the Blokelv-1 borehole, Jameson Land Basin, East Greenland
}

\author{
Lotte Melchior Larsen
}

\begin{abstract}
The fully cored Upper Jurassic succession in the Blokelv-1 borehole in the Jameson Land Basin, East Greenland, is intersected by igneous intrusions at four levels; the intrusions comprise a c. $15 \mathrm{~cm}$ thick dyke and three sills with thicknesses of $0.7,1.2$ and $1.9 \mathrm{~m}$. The sills consist of fine-grained, sparsely plagioclase-olivine-phyric basalt with chilled contacts to the sediments. Analyses of two sills gave very similar results. The sills are tholeiitic basalts with compositions similar to the main group of dykes and sills in the Jameson Land Basin, and the Blokelv- 1 sills are thus considered to belong to this group which has been dated at $c .53 \mathrm{Ma}$. The intrusions form part of a 55-51 Ma suite of tholeiitic basalt intrusions that was emplaced over an area extending for over $500 \mathrm{~km}$ north-to-south within the sedimentary basins of East and North-East Greenland.
\end{abstract}

Keywords: East Greenland, dykes, Cenozoic

L.M.L., Geological Survey of Denmark and Greenland, Øster Voldgade 10, DK-1350 Copenhagen K, Denmark.

E-mail:lml@geus.dk

The fully cored Blokelv-1 borehole was drilled in 2008 through Upper Jurassic sediments in the Jameson Land Basin, East Greenland (Bojesen-Koefoed et al. 2009), in order to study the sedimentary succession (Fig. 1A). The sediments in Jameson Land are intruded by many Cenozoic dykes and sills (e.g. Noe-Nygaard 1976; Hald \& Tegner 2000), and one of the site selection criteria was to minimise the risk of encountering thick igneous intrusions during drilling. Although major intrusions were avoided, the $233.8 \mathrm{~m}$ succession in the Blokelv-1 core is cut by intrusive igneous rocks at four levels with a combined thickness of $4.1 \mathrm{~m}$ (Fig. 1B). The purpose of this paper is to present descriptions and analyses of these intrusions and compare them with other Cenozoic dyke and sill intrusions in northern East Greenland.

\section{Intrusions in the Blokelv-1 core}

The core is cut by igneous intrusions at four levels in the upper half of the section: 102.04-100.1 m (thickness
$1.9 \mathrm{~m}), 56.4-55.2 \mathrm{~m}$ (thickness $1.2 \mathrm{~m}$ ), 27.10-26.40 m (thickness $0.70 \mathrm{~m}$ ) and 7.35-7.05 $\mathrm{m}$ (thickness $0.3 \mathrm{~m}$ ). The uppermost intrusion has oblique boundary contacts, dipping at $60^{\circ}$, and is accordingly described as a dyke; its true thickness must be $c .15 \mathrm{~cm}$. The three lower intrusions show boundary contacts that are broadly parallel to bedding in the host rock and thus appear to be sills. The two thickest sills have caused prominent alteration of the surrounding sediments (see Olivarius et al. 2018, this volume).

The thin dyke uppermost in the section (Fig. 1B) is thoroughly altered and was not studied further. The remaining three sills are lithologically similar and consist of fine-grained, sparsely plagioclase-olivine-phyric basalt. At the chilled contacts, they are very fine-grained to aphanitic, altered, and cut by carbonate veins. In the middle sill, a fracture is filled with biodegraded oil (BojesenKoefoed et al. 2018, this volume). 

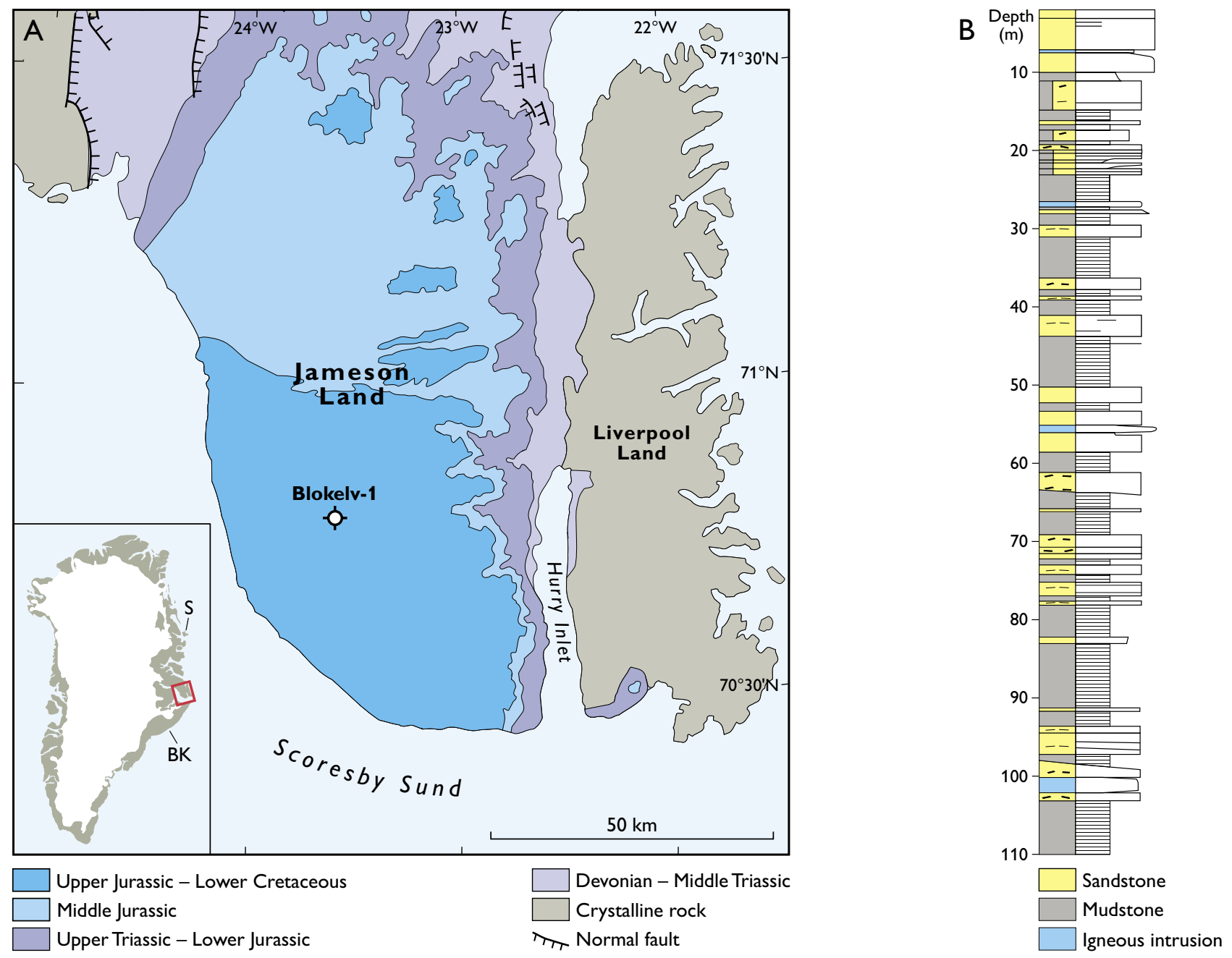

Fig. 1. A: Map of central and southern Jameson Land showing the location of the Blokelv-1 borehole $\left(70^{\circ} 45.305^{\prime} \mathrm{N}, 23^{\circ} 40.430^{\prime} \mathrm{W}, \mathrm{WGS} 84\right.$ coordinates); inset shows the location of the study area in East Greenland. BK: Blosseville Kyst. S: Shannon. B: Simplified log of the upper part $(0-110 \mathrm{~m})$ of the Blokelv-1 core (GGU no. 511101).

\section{Petrography}

The $1.9 \mathrm{~m}$ thick lower sill (Fig. 1B, 102.04-100.1 m) has a lower chilled margin that is aphanitic with many plagioclase microlites, sparse $0.1-0.2 \mathrm{~mm}$ plagioclase microphenocrysts, and a few plagioclase-olivine glomerocrysts with up to $2 \mathrm{~mm}$ plagioclase laths and $0.8 \mathrm{~mm}$ olivine crystals. Plagioclase is fresh but the olivine is completely altered. The groundmass is extensively replaced by carbonate, but plagioclase phenocrysts are fresh. The rock is cut by $0.1-0.5 \mathrm{~mm}$ wide veins of ankerite with patches of pyrite which cut both sill and sandstone at the contact (Fig. 2; see Olivarius et al. 2018, this volume). The veins are thickest at the contact. The veins in the sandstone appear to fill tension cracks.

The $1.2 \mathrm{~m}$ thick middle sill (Fig. 1B, 56.4-55.2 m) has a very fine-grained upper chilled margin with sparse
$0.5 \mathrm{~mm}$ plagioclase microphenocrysts and tiny $<0.5 \mathrm{~mm}$ euhedral olivine crystals; all olivine crystals are altered to clay. The groundmass is intersertal with numerous plagioclase microlites. The central part of the sill is finegrained with sparse $<1 \mathrm{~mm}$ plagioclase phenocrysts and sparse $c .0 .5 \mathrm{~mm}$ fresh olivine microphenocrysts, often assembled in glomerocrysts. The groundmass is intergranular with plagioclase, clinopyroxene, Fe-Ti oxide, olivine, and abundant mesostasis.

The $0.7 \mathrm{~m}$ thick upper sill (Fig. 1B, 27.10-26.40 m) is a fine-grained, nearly aphyric rock with scattered vugs filled with colourless minerals. The lower contact is not preserved. The rock becomes slightly finer grained towards the upper contact and there is possibly a thin glass chill at the top. There is no visible influence on the overlying sediments. 


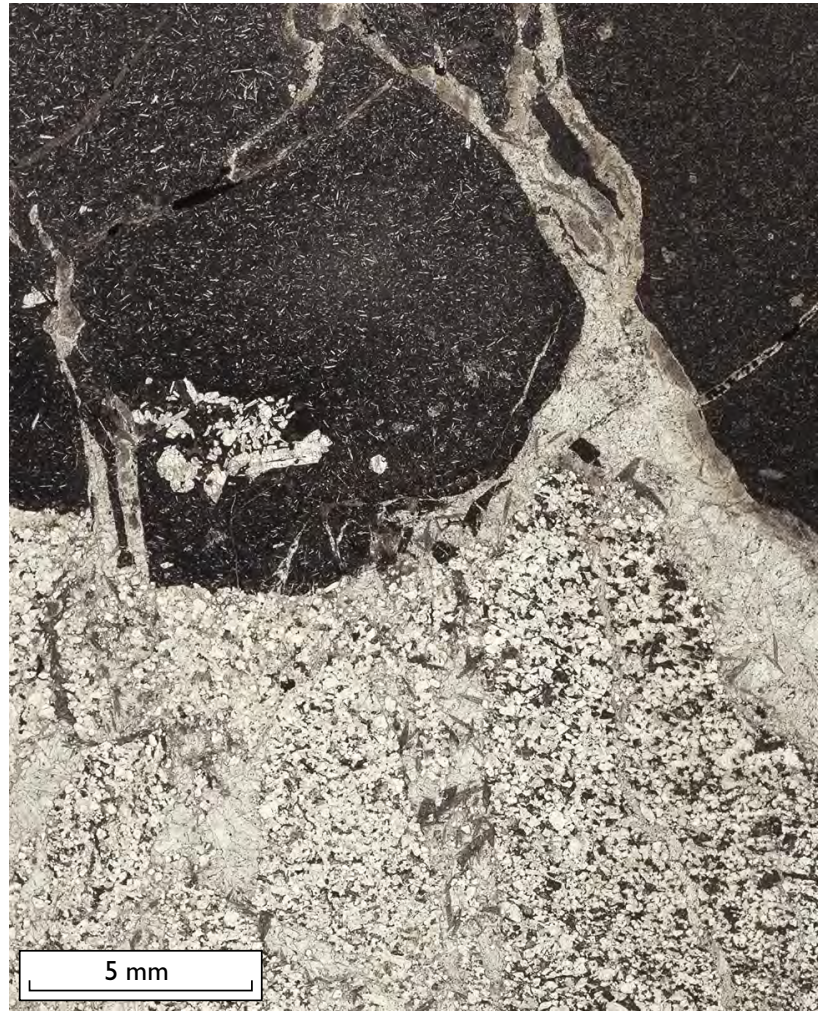

Fig. 2. Lower contact towards sandstone of the $1.9 \mathrm{~m}$ thick lower sill at $102.04 \mathrm{~m}$ in the core. Two ankerite veins cross both sill and sandstone. Note plagioclase-olivine glomerocryst in the very fine-grained basalt matrix between the two veins. Thin section 511101.246; plane-polarised light.

\section{Chemical compositions}

Two samples from the centres of the lower and middle sills have been analysed for major and trace elements. Major elements were analysed by N. Odling at University of Edinburgh by X-ray fluorescence spectrometry (XRF) and procedures as described by Fitton et al. (1998). Trace elements were analysed in GEUS' Rock Geochemical Laboratory using a PerkinElmer Elan 6100 DRC Quadrupole Inductively Coupled Plasma Mass Spectrometer (ICP-MS). Sample dissolution followed a modified version of the procedure used by Turner $e t$ al. (1999) and Ottley et al. (2003). Calibration was done using two certified REE solutions and three international reference standards. Results for reference samples processed and run simultaneously with the unknowns are normally within $5 \%$ of the reference value for most elements with concentrations $>0.1 \mathrm{ppm}$ (results are shown in Table 1).

The two sills consist of tholeiitic basalt with $6-7 \mathrm{wt} \%$ $\mathrm{MgO}$ and 2.1-2.3 $\mathrm{wt} \% \mathrm{TiO}_{2}$. Losses on ignition are low and the samples appear to be fresh. Measured values of tantalum $(\mathrm{Ta})$ are high (1.1-1.4 ppm) where only c. 0.8
Table 1. Chemical analyses of two sills in the Blokelv core, with comparisons from Jameson Land

\begin{tabular}{|c|c|c|c|c|}
\hline \multirow[b]{2}{*}{ Depth (m) } & \multirow{2}{*}{$\begin{array}{c}\text { Middle sill } \\
55.2-56.4\end{array}$} & \multirow{2}{*}{$\begin{array}{c}\text { Lower sill } \\
100.1-102\end{array}$} & \multicolumn{2}{|c|}{ Jameson Land } \\
\hline & & & ENE dyke & Thin sill \\
\hline GGU no & 511101.230 & 511101.229 & 407203 & 403021 \\
\hline \multicolumn{5}{|c|}{ Major elements, wt\% (XRF analyses) } \\
\hline $\mathrm{SiO}_{2}$ & 47.84 & 48.43 & 48.34 & 48.30 \\
\hline $\mathrm{TiO}_{2}$ & 2.30 & 2.11 & 2.35 & 2.33 \\
\hline $\mathrm{Al}_{2} \mathrm{O}_{3}$ & 13.71 & 12.87 & 13.79 & 13.80 \\
\hline $\mathrm{Fe}_{2} \mathrm{O}_{3}$ & 14.07 & 12.95 & 14.07 & 14.07 \\
\hline $\mathrm{MnO}$ & 0.21 & 0.26 & 0.20 & 0.20 \\
\hline $\mathrm{MgO}$ & 6.85 & 6.24 & 6.99 & 6.96 \\
\hline $\mathrm{CaO}$ & 11.23 & 12.08 & 11.52 & 11.47 \\
\hline $\mathrm{Na}_{2} \mathrm{O}$ & 2.23 & 2.03 & 2.39 & 2.37 \\
\hline $\mathrm{K}_{2} \mathrm{O}$ & 0.22 & 0.40 & 0.29 & 0.30 \\
\hline $\mathrm{P}_{2} \mathrm{O}_{5}$ & 0.20 & 0.19 & 0.24 & 0.23 \\
\hline LOI & 0.47 & 1.84 & -0.27 & 0.14 \\
\hline Sum & 99.33 & 99.40 & 99.91 & 100.17 \\
\hline \multicolumn{5}{|c|}{ Trace elements, ppm (ICP-MS analyses) } \\
\hline Sc & 38 & 36 & 40 & 38 \\
\hline V & 374 & 345 & 371 & 362 \\
\hline $\mathrm{Cr}$ & 190 & 179 & 259 & 249 \\
\hline Co & 55 & 50 & 53 & 52 \\
\hline $\mathrm{Ni}$ & 99 & 90 & 121 & 109 \\
\hline $\mathrm{Cu}$ & 240 & 218 & 256 & 249 \\
\hline $\mathrm{Zn}$ & 108 & 100 & 114 & 115 \\
\hline Ga & 21.0 & 20.0 & & \\
\hline $\mathrm{Rb}$ & 3.4 & 8.7 & 5.3 & 6.3 \\
\hline $\mathrm{Sr}$ & 217 & 230 & 237 & 228 \\
\hline Y & 31.1 & 30.5 & 32.1 & 31.7 \\
\hline $\mathrm{Zr}$ & 145 & 135 & 159 & 159 \\
\hline $\mathrm{Nb}$ & 12.1 & 11.7 & 12.6 & 12.8 \\
\hline Cs & 0.52 & 0.20 & 0.48 & 0.12 \\
\hline $\mathrm{Ba}$ & 130 & 110 & 71.6 & 71.9 \\
\hline $\mathrm{La}$ & 10.5 & 11.6 & 10.7 & 10.9 \\
\hline $\mathrm{Ce}$ & 27.2 & 29.9 & 28.0 & 28.0 \\
\hline $\operatorname{Pr}$ & 4.10 & 4.27 & 4.16 & 4.17 \\
\hline $\mathrm{Nd}$ & 19.7 & 20.1 & 19.1 & 19.2 \\
\hline Sm & 5.09 & 5.01 & 5.15 & 5.27 \\
\hline Eu & 1.68 & 1.64 & 1.77 & 1.74 \\
\hline Gd & 6.07 & 5.79 & 5.42 & 5.30 \\
\hline $\mathrm{Tb}$ & 0.99 & 0.91 & 0.94 & 0.93 \\
\hline Dy & 5.78 & 5.45 & 5.49 & 5.36 \\
\hline Ho & 1.14 & 1.07 & 1.13 & 1.10 \\
\hline $\mathrm{Er}$ & 3.09 & 2.95 & 2.91 & 2.87 \\
\hline $\mathrm{Tm}$ & 0.47 & 0.44 & 0.43 & 0.43 \\
\hline Yb & 2.77 & 2.69 & 2.65 & 2.61 \\
\hline Lu & 0.41 & 0.39 & 0.36 & 0.38 \\
\hline $\mathrm{Hf}$ & 3.77 & 3.47 & 3.60 & 3.57 \\
\hline $\mathrm{Ta}$ & & & 0.84 & 0.84 \\
\hline $\mathrm{Pb}$ & 0.91 & 5.61 & 1.29 & 1.71 \\
\hline Th & 0.84 & 1.25 & 0.9 & 0.89 \\
\hline$U$ & 0.26 & 0.29 & 0.31 & 0.31 \\
\hline
\end{tabular}

Total iron is reported as $\mathrm{Fe}_{2} \mathrm{O}_{3}$. $\mathrm{LOI}$ is loss on ignition Data for Jameson Land from Hald \& Tegner (2000).

ppm Ta is expected; this may be contamination from the tungsten carbide crushing vessel and the data are not included in Table 1. The lower sill has $5.6 \mathrm{ppm} \mathrm{Pb}$ which is very high, indicating contamination with $\mathrm{Pb}$ either during emplacement or from the drilling process; there is no evidence of additional contamination. 

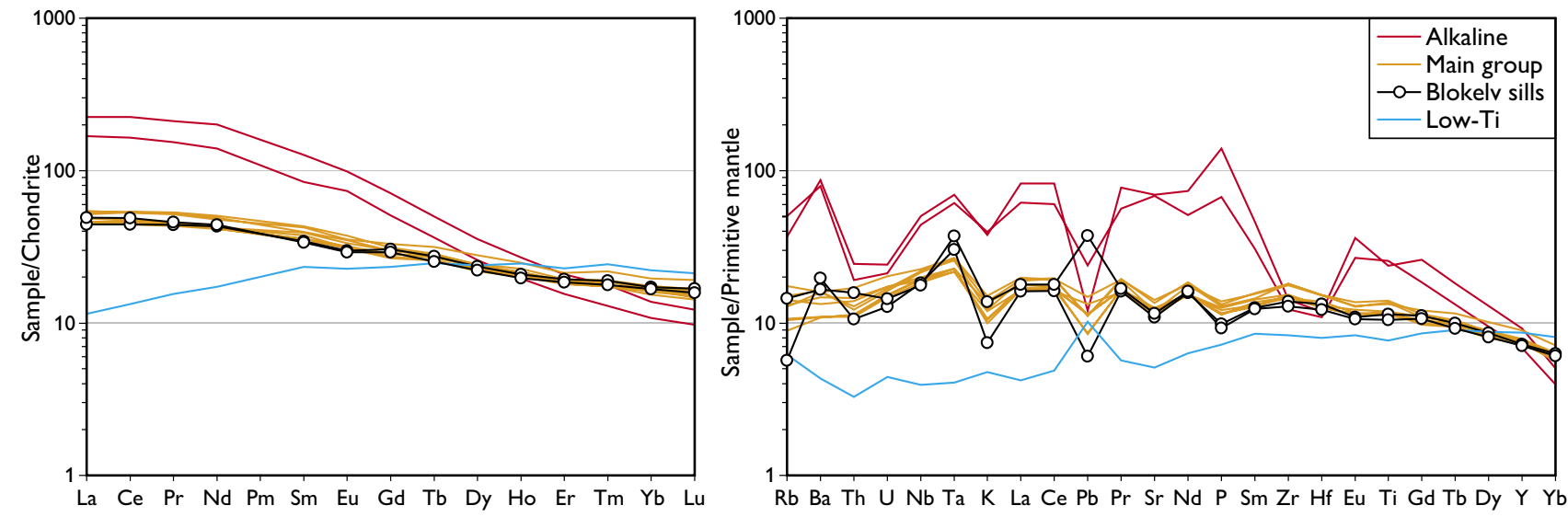

Fig. 3. Multi-element patterns for the Blokelv sills compared with sills and dykes in the Jameson Land Basin (data from Hald \& Tegner 2000). Alkaline and Low-Ti basalt are two other basalt groups defined by Hald \& Tegner (2000). Note the close similarity between the main group of intrusions and the Blokelv sills. The high $\mathrm{Pb}$ in one of the Blokelv samples must be due to contamination.

\section{Discussion}

The two analysed sills have very similar compositions and are considered to have been intruded during the same magmatic event. The tholeiitic basalt represents a magma type that is known from widespread sills and dykes in the Jameson Land Basin (Larsen et al. 1989; Hald \& Tegner 2000). Hald \& Tegner (2000) recognised five different magma types represented by sills and dykes, and by far the most common group is the one found in the Blokelv sills. This group was called the 'High-Ti group' by Hald \& Tegner (2000), but as the Ti contents are not high, it is referred to here as the 'main group'. Figure 3 shows geochemical patterns for the Blokelv sills compared with similar patterns for the Jameson Land sills and dykes. The close similarity of the Blokelv sills with the main group of tholeiitic sills and dykes in Jameson Land is clear.

The Blokelv intrusions are poorly suited for ${ }^{39} \mathrm{Ar} /{ }^{40} \mathrm{Ar}$ dating because of the low $\mathrm{K}_{2} \mathrm{O}$ content and few and small plagioclase phenocrysts. However, Hald \& Tegner (2000) dated a sill and a dyke from the main group by the ${ }^{39} \mathrm{Ar} /{ }^{40} \mathrm{Ar}$ method. The sill yielded a 5-point isochron age of $52.7 \pm 1.2 \mathrm{Ma}$, and the dyke yielded a four-point isochron age of $53.3 \pm 1.4 \mathrm{Ma}$; the two ages are within the uncertainty of each other (the ages are here recalculated to an age of $28.201 \mathrm{Ma}$ for the Fish Canyon Tuff standard). It is therefore most probable that the two Blokelv sills were emplaced at $c .53 \mathrm{Ma}$.

The intrusions in the Jameson Land Basin were emplaced after the plateau lavas of the Blosseville Kyst at 56.4-55.3 Ma (Storey et al. 2007) and after or just concomitantly with the plateau lavas in north-eastern Greenland at 56-53 Ma (Larsen et al. 2014). They are within the age range of 55-51 Ma obtained for tholeiitic sills and dykes intruded into the sediments from Jameson Land in the south to the island of Shannon in the north (Hald \& Tegner 2000; Larsen et al. 2014). Most intrusion ages are in the interval 54-52 Ma and magma production at that time must have been very extensive. These intrusions cover a stretch of least $500 \mathrm{~km}$ which is close to the entire onshore extent of the Mesozoic basins.

The intrusions are older than the Igtertivâ Formation at Kap Dalton on the Blosseville Kyst which comprises two parts dated at $49.1 \pm 0.5 \mathrm{Ma}$ and $43.8 \pm 1.1$ $\mathrm{Ma}$ (Larsen et al. 2013). Larsen et al. (2013) found significant geochemical differences between the Igtertivâ Formation basalts and the underlying 55 Ma lavas of the Skrænterne Formation, in particular in the rare-earth element (REE) ratios. As seen in Fig. 4, the intrusions at 55-51 Ma retained the geochemical characteristics of the older plateau lavas, indicating that the conditions of magma generation were unchanged, probably mainly governed by the relatively thick lithosphere beneath the continent away from the developing oceanic rift (Hald \& Tegner 2000).

\section{Conclusions}

The two analysed sills in the Blokelv-1 core are compositionally similar to the main group (high-Ti group) of tholeiitic basalt sills and dykes that occur frequently in the Jameson Land Basin, of which two have been dated at $c .53 \mathrm{Ma}$. The Blokelv sills are considered to belong to this group. The group shares trace element characteristics 


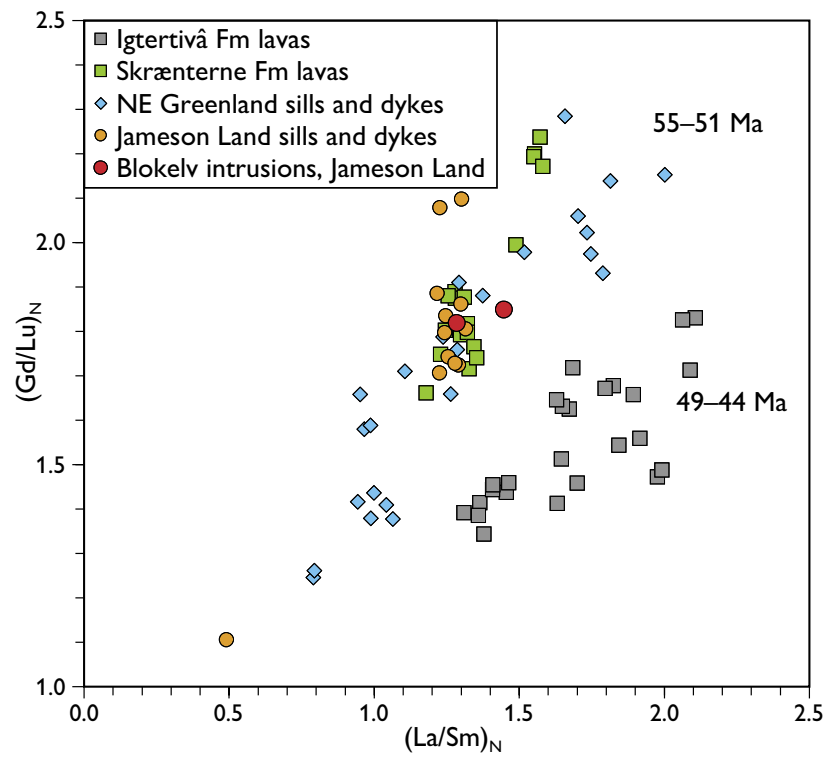

Fig. 4. Rare-earth element (REE) ratios for older (55-51 Ma) lavas and intrusions (Blosseville Kyst to Shannon) and younger (49-44 $\mathrm{Ma}$ ) Igtertivâ Formation lavas on Blosseville Kyst, East Greenland. Data from Hald \& Tegner (2000), Larsen et al. (2013), Larsen et al. (2014) and unpublished GEUS data (2008-2010). A few crustally contaminated samples are not plotted. $\mathrm{La} / \mathrm{Sm}$ is the light $\mathrm{REE}$ ratio and $\mathrm{Gd} / \mathrm{Lu}$ is the heavy REE ratio; $\mathrm{N}$ designates chondrite-normalised concentrations.

with the older Blosseville Kyst lavas and the 55-51 Ma tholeiitic sills and dykes in East Greenland, but not with the younger 49-54 Ma Igtertivâ Formation lavas. The older magmas were probably generated under similar conditions beneath relatively thick lithosphere.

\section{Acknowledgements}

The referees, Godfrey Fitton and Christian Tegner, are thanked for their constructive comments.

\section{References}

Bojesen-Koefoed, J.A., Bjerager, M. \& Piasecki, S. 2009: Shallow core drilling and petroleum geology related field work in East and North-East Greenland 2008. Geological Survey of Denmark and Greenland Bulletin 17, 53-56.

Bojesen-Kofoed, J., Bjerager, M., Nytoft, H.P., Petersen, H.I., Pia- secki, S. \& Pilgaard, A. 2018: Petroleum potential of the Upper Jurassic Hareelv Formation, Jameson Land, East Greenland. In: Ineson, J. \& Bojesen-Koefoed, J.A. (eds): Petroleum geology of the Upper Jurassic - Lower Cretaceous of East and North-East Greenland: Blokelv-1 borehole, Jameson Land Basin. Geological Survey of Denmark and Greenland Bulletin 42, 85-113 (this volume).

Fitton, J.G., Saunders, A.D., Larsen, L.M., Hardarson, B.S. \& Norry, M.J. 1998: Volcanic rocks from the southeast Greenland margin at $63^{\circ} \mathrm{N}$ : composition, petrogenesis and mantle sources. In: Saunders, A.D., Larsen, H.C. \& Wise, S.W., Jr. (eds): Proceedings of the Ocean Drilling Program, Scientific Results 152, 331-350. College Station, TX.

Hald, N. \& Tegner, C. 2000: Composition and age of Tertiary sills and dykes, Jameson Land Basin, East Greenland: relation to regional flood volcanism. Lithos 54, 207-233.

Larsen, L.M., Watt, W.S. \& Watt. M. 1989: Geology and petrology of the Lower Tertiary plateau basalts of the Scoresby Sund region, East Greenland. Bulletin Grønlands Geologiske Undersøgelse 157, $164 \mathrm{pp}$.

Larsen, L.M., Pedersen, A.K., Sørensen, E.V., Watt, W.S. \& Duncan, R.A. 2013: Stratigraphy and age of the Eocene Igtertivâ Formation basalts, alkaline pebbles and sediments of the Kap Dalton Group in the graben at Kap Dalton, East Greenland. Bulletin of the Geological Society of Denmark 61, 1-18.

Larsen, L.M., Pedersen, A.K., Tegner, C. \& Duncan, R.A. 2014: Eocene to Miocene igneous activity in NE Greenland: northward younging of magmatism along the East Greenland margin. Journal of the Geological Society (London) 171, 539-553.

Noe-Nygaard, A. 1976: Tertiary igneous rocks between Shannon and Scoresby Sund, East Greenland. In: Escher, A. \& Watt, W.S. (eds): Geology of Greenland, 386-402. Copenhagen: Geological Survey of Greenland.

Olivarius, M., Weibel, R., Schovsbo, N.H., Olsen, D. \& Kjøller, C. 2018: Diagenesis of Upper Jurassic sandstones of the Blokelv-1 core in the Jameson Land Basin, East Greenland. In: Ineson, J. \& Bojesen-Koefoed, J.A. (eds): Petroleum geology of the Upper Jurassic - Lower Cretaceous of East and North-East Greenland: Blokelv-1 borehole, Jameson Land Basin. Geology of Denmark and Greenland Survey Bulletin 42, 65-84 (this volume).

Ottley, C.J., Pearson, D.G. \& Irvine, G.J. 2003: A routine method for the dissolution of geological samples for the analysis of REE and trace elements via ICP-MS. In: Holland, J.G. \& Tanner, S.D. (eds): Plasma source mass spectrometry: Applications and emerging technologies, 221-230. Cambridge: Royal Society of Chemistry.

Storey, M., Duncan, R.A. \& Tegner, C. 2007: Timing and duration of volcanism in the North Atlantic Igneous Province: Implications for geodynamics and links to the Iceland hotspot. Chemical Geology 241, 264-281.

Turner, S.P., Platt, J.P., George, R.M.M., Kelly, S.P., Pearson, D.G. \& Nowell, G.M. 1999: Magmatism associated with orogenic collapse of the Betic-Alboran domain, SE Spain. Journal of Petrology $\mathbf{4 0 ,}$ 1011-1036. 